\title{
HUBUNGAN PENDEKATAN LINGKUNGAN ALAM SEKITAR (PLAS) DENGAN HASIL BELAJAR SISWA KELAS V SEKOLAH DASAR
}

\author{
Hidayah Mulyaningsih Suprapto \\ Pendidikan Dasar \\ Universitas Negeri Yogyakarta \\ mshidayah21@gmail.com
}

\begin{abstract}
This study aims to determine the relationship between the approach of the natural environment with the learning outcomes of students in grade V SD N 3 Klaten Grabag Magelang. The learning that is happening now has increased material that is taught increasingly difficult how to teach teachers is still conventional lack of media and facilities learning especially in natural science learning that requires concrete understanding. For this reason teachers need to innovate in learning one of them using the natural environment approach that can be used in science subjects. The subjects of this study were students of grade V SD N 3 Klaten as many as 32 children 16 children of the experimental group and 16 control groups selected by the object random sampling system in this study were natural science learning outcomes using a natural environment approach around data collection techniques used in the form of observation and documentation. this type of research is a quasi-experimental with pretest posttest control group design research method used is quantitative data analysis techniques in this study using $t$ test with a significance level of 5\%. The results of the study showed that the experimental group obtained the calculated thitung $(7,580)>t_{\text {tabel(df:15) }}(2,145)$, and the $p(0,000)<$ dari 0,05 value with the results of the study meant that there was an increase in student learning outcomes in grade VSD N 3 Klaten using a significant natural environment approach to student learning outcomes so that it could be concluded that there was a significant relationship between the approaches the surrounding natural environment with student learning outcomes in the material Adjustment of living things with the environment in grade V SD Negeri 3 Klaten Grabag Magelang.
\end{abstract}

Keywords: PLAS, learning outcomes, IPA

\begin{abstract}
ABSTRAK
Penelitian ini bertujuan untuk mengetahui Hubungan Pendekatan Lingkungan Alam Sekitar (PLAS) dengan hasil belajar siswa kelas V SD N 3 Kleteran Grabag Magelang.Pembelajaran yang terjadi saat ini sudah semakin meningkat, materi yang diajarkan semakin sulit, cara mengajar guru masih konvensional, kurangnya media dan fasilitas pembelajaran terutama dalam pembelajaran IPA yang membutuhkan pemahaman secara konkret. Untuk itu guru perlu malakukan inovasi dalam pembelajaran salah satunya menggunakan Pendekatan Lingkungan Alam Sekitar (PLAS) yang dapat digunakan pada pelajaran IPA. Subjek penelitian ini adalah siswa kelas V SD N 3 Kleteran sebanyak 32 anak (16 anak kelompok eksperimen dan 16 kelompok kontrol) yang dipilih dengan sistem
\end{abstract}


Random Sampling. Objek dalam penelitian ini adalah hasil belajar IPA menggunakan Pendekatan Lingkungan Alam Sekitar (PLAS). Teknik pengumpulan data yang digunakan berupa observasi, tes, dan dokumentasi. Jenis penelitian yang digunakan adalah quasi eksperimen dengan pretest posttest control group design, metode penelitian yang digunakan adalah kuantitatif. Teknik analisis data dalam penelitian ini mengggunakan uji $t$ dengan taraf signifikan $5 \%$. Hasil penelitian menunjukan pada kelompok eksperimen diperoleh nilai $\mathrm{t}_{\text {hitung }}(7,580)>\mathrm{t}_{\text {tabel(df:15) }}(2,145)$, dan nilai $p(0,000)<$ dari 0,05 , dengan hasil penelitian tersebut diartikan bahwa ada peningkatan hasil belajar siswa kelas V SD N 3 Kleteran menggunakan pendekatan lingkungan alam sekitar (PLAS) yang signifikan terhadap hasil belajar siswa. Sehingga dapat disimpulkan terdapat hubungan yang signifikan antara pendekatan lingkungan alam sekitar dengan hasil belajar siwa pada materi penyesuain diri makhluk hidup dengan lingkungan di kelas V SD Negeri 3 Kleteran Grabag Magelang.

Kata kunci: PLAS, hasil belajar, IPA

\section{PENDAHULUAN}

IPA berhubungan dengan cara mencari tahu tentang alam secara sistematis, sehingga bukan hanya penguasaan kumpulan pengetahuan yang berupa fakta-fakta, konsep-konsep atau prinsip-prinsip saja tetapi juga merupakan suatu proses penemuan. Pendidikan IPA diharapkan dapat menjadi wahana bagi peserta didik untuk mempelajari diri sendiri dan alam sekitar, serta prospek pengembangan lebih lanjut untuk menerapkannya dalam kehidupan sehari-hari. Proses pembelajarannya menekankan pada pemberian pengalaman langsung untuk mengembangkan kompetensi agar menjelajahi dan memahami alam sekitar secara ilmiah (Mulyasa, 2011:110).

Pada tingkat Sekolah Dasar Kelas V, salah satu materi yang diajarkan yaitu tentang penyesuaian diri makhluk hidup dengan lingkungan sesuai dengan Standar Kompetensi (SK) yaitu mengidentifikasi cara makhluk hidup menyesuaikan diri dengan lingkungan. Sedangkan Kompetensi Dasar (KD) yang sesuai dengan SK yaitu mengidentifikasi penyesuaian diri tumbuhan dengan lingkungan tertentu untuk mempertahankan hidup (Mulyasa,2011:120). Pada materi tersebut, siswa diajarkan untuk mengidentifikasi cara makhluk hidup yaitu tumbuhan dan hewan dalam menyesuaikan diri dengan lingkungan untuk memahami materi ini siswa dilatih untuk menganalisis makhluk hidup sekitar dalam mempertahankan diri di lingkungan tempat tinggalnya.

Hasil belajar yang dicapai siswa dalam materi tersebut akan berpengaruh pada aspek kognitif dan afektif siswa. Segi kognitif, siswa akan memperoleh pemahaman dan analisis makhluk hidup khususnya tumbuhan untuk mempertahankan hidupnya. Sedangkan dalam segi afektif, siswa dapat menumbuhkan cinta alam, kesadaran untuk menjaga dan memelihara lingkungan dan menanggulangi pencemaran lingkungan

Berdasarkan hasil observasi yang dilakukan peneliti di SD N 3 Kleteran, Grabag Magelang, pada implementasinya khususnya pada kelas V, proses dan hasil pembelajaran IPA, masih tergolong rendah. Siswa beramsumsi bahwa IPA merupakan mata pelajaran yang sulit dipelajari. Pada saat pembelajaran IPA berlangsung siswa cenderung mengobrol sendiri, bersifat pasif serta siswa kurang tertarik dalam pembelajaran sehingga siswa cepat merasa bosan. Selain itu, pembelajaran yang dilakukan masih konvensional dan rendahnya minat dan motivasi siswa ketika mempelajari materi pembelajaran. Guru cenderung hanya mentransfer berbagai macam informasi yang tercantum pada buku teks. Hal ini menyebabkan siswa mengalami penurunan dalam kreatifitas dan semangat belajar di sekolah. 
Melihat kondisi tersebut, tentunya perlu dicari solusi yang dapat memudahkan siswa untuk memahami materi yang disampaikan. Proses belajar mengajar tidak bisa terlepas dari peran media, sebab media pembelajaran merupakan suatu bagian integral dari proses pendidikan di sekolah. Media diperlukan karena belajar akan lebih baik bila melibatkan banyak indera. Dengan adanya media, siswa tidak hanya mengaktifkan indera penglihatan, perasa dan sebagainya. Upaya yang dilakukan untuk memperbaiki mutu pendidikn danmengatasi permasalahan-permaslahan yang sudah dikemukakan diata adalah dengan menerapkan pendekatan lingkungan alam sekitar yang inovatif agar dapat meningkatkan hasil belajar IPA.

Berawal dari hal diatas, perlu satu perbaikan terutama hasil belajar yang diyakini dapat meningkatkan hasil belajar siswa. Guru dapat menggunakan pendekatan pembelajaran yang sesuai sebagai sarana untuk mengemas suatu pembelajaran yang terarah dan berkesinambungan sesuai dengan kemampuan siswa melalui tahapan-tahapan pembelajaran yang sesuai dengan materi yang diajarkan. Pendekatan Lingkungan Alam Sekitar (PLAS) merupakan suatu pendekatan pembelajaran yang berusaha untuk meningkatkan keterlibatan siswa melalui pendayagunaan lingkungan sebagai sumber belajar. Menurut Uno dan Mohammad (2015:147) mengatakan bahwa "konsep pembelajaran dengan menggunakan lingkungan memberikan peluang yang sangat besar kepada peserta didik untuk meningkatkan hasil belajarnya”. Dengan PLAS siswa dapat terlibat melalui pendayagunaan lingkungan sebagai sumber belajar. Mengajar dengan pendekatan lingkungan alam sekitar diimplikasikan dengan kegiatan diluar kelas sangat penting dalam rangka melibatkan anak didik untuk mencari pengalaman belajarnya. Didalam cara ini siswa dimotivasi untuk menggunakan semua inderanya didalamanya kegiatan lingkungan alam sekitar, yang mereka ketahui. Segala pengalaman tersebut merupakan argumen untuk menyusun kembali, menambah dan menyempurnakan atau menggantikan pengalaman pertama yang diperoleh dari sesuatu yang telah dilihat sebelumnya.

Adapun kelebihan PLAS menurut Uno dan Muhammad (2015:146-148) yaitu: a) Peserta didik dibawa langsung ke dalam dunia yang konkret tentang penanaman konsep pembelajaran, sehingga peserta didik tidak hanya bisa untuk mengkhayalkan materi; b) Lingkungan dapat digunakan setiap saat, kapan pun dan dimanapun sehingga tersedia setiap saat, tetapi tergantung dari jenis materi yang diajarkan; c) Konsep pembelajaran dengan menggunakan lingkungan tidak membutuhkan biaya karena semua telah disediakan oleh alam lingkungan; d)Mudah untuk dicerna oleh peserta didik karena peserta didik disajikan materi yang sifatnya konkret bukan abstrak; e) Motivasi belajar peserta didik akan lebih bertambah karena peserta didik mengalami suasana belajar yang berbeda dari biasnya; f) Suasana yang nyaman memungkinkan peserta didik tidak mengalami kejenuhan ketika menerima materi; g) Memudahkan untuk mengontrol kebiasaan buruk dari sebagian peserta didik; h) Membuka peluang kepada peserta didik untuk berimajinasi; i) Konsep pembelajaran yang dilakukan tidak terkesan monoton; j) Peserta didik akan lebih leluasa dalam berpikir dan cenderung untuk memikirkan materi yang diajarkan karena materi yang diajarkan telah tersaji di depan mata (konkret). Sehingga siswa dapat memahami materi yang diajarkan guru. Dengan demikian, hasil belajar yang diperoleh siswa juga akan berpengaruh.

Menurut Sudjana (2016:3) mengungkapkan hasil belajar siswa pada hakikatnya adalah "perubahan tingkah laku sebagai hasil belajar dalam pengertian yang lebih luas mencakup bidang kognitif, afektif dan psikomotorik". Sedangkan nenurut Dimyati dan Mudjiono (2013:3) hasil belajar merupakan "hasil dari suatu interaksi tindak belajar dan tindak mengajar". Dari sisi guru, tindak mengajar diakhiri dengan proses evaluasi hasil 
belajar. Dari sisi siswa hasil belajar merupakan berakhirnya pengajaran puncak proses belajar. Maka, pengkajian yang ingin dilakukan adalah tentang bagaimana hubungan Pendekatan LIngkungan Alam Sekitar (PLAS) dengan Hasil Belajar Siswa Kelas V SD N 3 Kleteran Materi Penyesuaian Diri Makhluk Hidup.

\section{METODE PENELITIAN}

Jenis penelitian yang digunakan adalah quasi eksperimen dengan pretest posttest control group design. Penelitian ini dilaksanakan di SD Negeri 3 Kleteran Grabag Magelang pada akhir bulan Agustus hingga September 2017 yang disesuaikan dengan jadwal pelajaran IPA. Populasi yang digunakan adalah seluruh siswa SD Negeri 3 Kleteran Grabag Magelang. Sedangkan sampel yang yang digunakan adalah siswa kelas V SD Negeri 3 Kleteran Grabag Magelang yang berjumlah 32 siswa yang dibagi menjadi 16 siswa sebagai kelompok eksperimen dan 16 siswa sebagai kelompok kontrol dengan melihat hasil UTS IPA semester II. Teknik pengambilan yang digunakan adalah teknik sampel random sederhana (Simple Random Sampling). Variabel bebas dalam penelitian ini adalah penggunaan pendekatan lingkungan alam sekitar untuk kelas eksperimen dan media gambar untuk kelas control. Sedangkan variabel terikatnya adalah hasil belajar siswa kelas V SD Negeri 3 Kleteran Grabag Magelang. Teknik pengumpulan data yang digunakan dalam penelitian ini adalah observasi, tes dan dokumentasi. Tes yang digunakan bertujuan untuk mengukur kemampuan siswa dalam hasil belajar siswa aspek kognitif. Tes tersebut menggunakan soal pre-test dan post-test dalam pedoman penilaian yang telah dimodifikasi untuk mengukur hasil belajar siswa. Instrumen yang digunakan dalam penelitian ini adalah lembar observasi dan perangkat tes. Lembar observasi yang dibuat berupa lembar observasi aktivitas dan sikap siswa pada saat pelaksanaan pembelajaran IPA dan lembar observasi aktivitas guru dalam pembelajaran di kelas. Perangkat tes yautu berupa soal pretest dan post-test untuk mengukur hasil belajar siswa. Perangkat tes yang digunakan untuk mengumpulkan data adalah tes pilihan ganda dengan satu jawaban benar sebanyak 20 butir.

Data yang dikumpulkan dalam penelitian ini adalah data hasil belajar siswa. Data yang telah dikumpulkan dianalisis dengan menggunakan statistik deskriptif dan statistik inferensial. Analisis deskriptif berfungsi untuk mengelompokkan data, menggarap, memaparkan serta menyajikan hasil olahan. Endeskripsian dilakukan dengan menggunakan komputer program SPSS versi 23.0, untuk mendapatkan mean dan standar deviasi dari masing-masing variabel. Distribusi frekuensi data dibuat dengan membuat kelas interval. Sedangkan analisis inferensial digunakan untuk menggeneralisasikan hasil penelitian yang dilakukan pada sampel bagi populasi. Analisis inferensial dilakukan melalui uji-t. Uji-t digunakan untuk menguji perbedaan rata-rata hitung hasil belajar siswa antara kelompok eksperimen yang diberi pembelajaran dengan pendekatan lingkungan alam sekitar dan kelompok kontrol yang diberi pembelajaran dengan media gambar. Analisis deskriptif dilakukan untuk mengetahui tinggi rendahnya kualitas dari dua variabel yaitu pendekatan lingkungan alam sekitar dan hasil belajar siswa. Untuk menentukan tinggi rendahnya kualiats variabel-variabel tersebut, skor rata-rata (mean) tiap-tiap variabel dikonversikan dengan menggunakan kriteria ideal dan standar deviasi (SD).

\section{HASIL DAN PEMBAHASAN}

Dalam memperoleh gambaran tentang hasil belajar IPA data dianalisis dengan analisis deskriptif agar dapat diketahui Mean (M), Median (Md), Modus (Mo) dan standar deviasi. Rangkuman hasil analisis disajikan dalam tabel berikut ini: 
Tabel 1. Hasil pelaksanaan pre-test

\begin{tabular}{clcc}
\hline No & \multicolumn{1}{c}{ Uraian } & Kelas Kontrol & Kelas Eksperimen \\
\hline 1. & Jumlah & 1050 & 1035 \\
\hline 2. & Nilai rata-rata & 65,62 & 64,68 \\
\hline 3. & Median & 70 & 67,5 \\
\hline 4. & Modus & 70 & 65 \\
\hline 5. & Nilai maksimum & 90 & 85 \\
\hline 6. & Nilai Minimum & 35 & 25 \\
\hline 7. & Standar Deviasi & 13,40 & 15,65 \\
\hline
\end{tabular}

Tabel 2. Hasil pelaksanaan post-test

\begin{tabular}{clcc}
\hline No & \multicolumn{1}{c}{ Uraian } & Kelas Kontrol & Kelas Eksperimen \\
\hline 1. & Jumlah & 1375 & 1390 \\
\hline 2. & Nilai rata-rata & 85,93 & 86,87 \\
\hline 3. & Median & 85 & 90 \\
\hline 4. & Modus & 75 & 90 \\
\hline 5. & Nilai maksimum & 100 & 100 \\
\hline 6. & Nilai Minimum & 75 & 70 \\
\hline 7. & Standar Deviasi & 8,60 & 7,72 \\
\hline
\end{tabular}

Berdasarkan tabel diatas, dapat disimpulkan hasil belajar IPA siswa kelas eksperimen cenderung tinggi sedangkan hasil belajar IPA siswa kelompok control cenderung rendah. Uji normalitas sebaran data dilakukan untuk membuktikan bahwa frekuensi data hasil penelitian benar-benar berdistribusi normal. Uji normalitas sebaran data dilakukan terhadap data hasil post-test kelas eksperimen dan kontrol. Normalitas variabel dilakukan dengan menggunakan rumus Kolmogrov-Smirnov. Kaidah yang digunakan untuk mengetahui normal tidaknya suatu sebaran adalah $p>0,05$ sebaran dinyatakan normal, dan jika $p<0,05$ sebaran dikatakan tidak normal.

Berdasarkan hasil perhitungan dengan menggunakan rumus Kolmogrov-Smirnov diperoleh nilai signifikansi $(p)$ hasil post-test kelas eskperimen sebesar 0,423 sedangkan hasil post-test kelas kontrol sebesar 0,768 . Hal ini berarti semua variabel adalah lebih besar dari 0.05, jadi, data adalah berdistribusi normal. Oleh karena semua data berdistribusi normal maka analisis dapat dilanjutkan dengan analisis statistik parametrik.

Berdasarkan hasil uji prasyarat analisis, diperoleh bahwa data hasil post-test kelas eksperimen dan kelas kontrol berdistribusi normal dan memilki varians yang homogen. Hasil uji homogenitas data hasil belajar IPA kelas eksperimen diperoleh nilai $r$ hitung $(3,065)$ $<\mathrm{r}$ tabel $(4,20)$, dengan hasil yang diperoleh tersebut dapat disimpulkan bahwa varians bersifat homogen. Sedangkan data hasil belajar pada kelas kontrol diperoleh nilai $r$ hitung $(1,195)<\mathrm{r}$ tabel $(4,20)$, dengan hasil yang diperoleh tersebut dapat disimpulkan bahwa varians bersifat homogen. Untuk menguji hipotesis menggunakan uji-t paired sampel t test pada taraf signifikan $5 \%$. Hasil uji -t dapat dilihat pada tabel di bawah ini:

Tabel. 3. Hasil Uji Hipotesis (Uji t)

\begin{tabular}{llllll} 
Pretest-posttest & df & $\mathbf{t}_{\text {tabel }}$ & $\mathbf{t}_{\text {hitung }}$ & P & Sig $5 \%$ \\
\hline
\end{tabular}




\begin{tabular}{lccccc}
\hline $\begin{array}{l}\text { Hasil Belajar Kelompok } \\
\text { Ekperimen }\end{array}$ & $\mathbf{1 5}$ & $\mathbf{2 , 1 4 5}$ & $\mathbf{7 , 5 8 0}$ & $\mathbf{0 , 0 0 0}$ & $\mathbf{0 , 0 5}$ \\
\hline Hasil belajar kelompok Kontrol & $\mathbf{1 5}$ & $\mathbf{2 , 1 4 5}$ & $\mathbf{7 , 6 8 9}$ & $\mathbf{0 , 0 0 0}$ & $\mathbf{0 , 0 5}$
\end{tabular}

Berdasarkan tabel diatas pada kelompok eksperimen diperoleh nilai $t_{\text {hitung }}(7,580)>t$ tabel(df:15) $(2,145)$, dan nilai $p(0,000)<$ dari 0,05 , berdasarkan hasil tersebut dapat diartikan ada penningkatan hasil belajar siswa kelas V SD N 3 Kleteran dengan Pendekatan Lingkungan Alam Sekitar (PLAS). Untuk mengukur besarnya peningkatan hasil belajar dengan Pendekatan Lingkungan Alam Sekitar (PLAS) dapat dihitung dengan mengetahui persentase peningkatan hasil belajar IPA.

$$
\text { Persentase peningkatan }=\frac{\text { mean different }}{\text { mean pretest }} \times 100 \%
$$

Hasil penelitian rata-rata pretest pada kelompok eksperimen diperoleh 64,68 sedangkan pada hasil posttest diperoleh sebesar 86,87 . Setelah diketahui nilai rata-rata pretest dan postest maka peningkatan persentasenya dapat dihitung sebagai berikut:

$$
\begin{gathered}
\text { Peningkatan Persentase }=\frac{64,68-86,67}{64,68} \times 100 \% \\
\text { Peningkatan Persentase }=33,99 \%
\end{gathered}
$$

Hasil tersebut dapat diartikan persentase peningkatan hasil belajar dengan Pendekatan Lingkungan Alam Sekitar (PLAS) diperoleh peningkatan persentasenya sebesar 33,99 \%. Hasil uji t pada kelompok kontrol diperoleh nilai $t_{\text {hitung }}(8,461)>\mathrm{t}$ tabel(df:15) $(2,120)$, dan nilai $p(0,000)<$ dari 0,05 , berdasarkan hasil tersebut dapat diartikan ada peningkatan hasil belajar siswa kelas V SD N 3 Kleteran PLAS dengan media gambar. Hasil statistik dekriptif hasil data hasil belajar IPA dengan media gambar diperoleh ratarata pretest sebesar 65,62, saat posttest sebesar 85,93, peningkatan persentasenya dapat dihitung sebagai berikut

$$
\text { Peningkatan Persentase }=\frac{65,62-85,93}{65,62} \times 100 \%
$$

\section{Peningkatan Persentase $=30,95 \%$}

Berdasarkan hasil tersebut dapat diartikan, peningkatan hasil belajar IPA menggunakan PLAS dengan media gambar diperoleh peningkatan persentasenya sebesar $30,95 \%$. Berdasarkan hasil observasi aktivitas belajar siswa, diperoleh data aktivitas belajar siswa pada masing-masing kelas sampel, yaitu pada kelas kontrol sebesar 9,18 , sedangkan kelas eksperimen sebesar 10,28. Berdasarkan nilai rata-rata tersebut kelas eksperimen memperoleh nilai rata-rata lebih tinggi dibandingkan kelas kontrol. Akan tetapi hasil konversi nilai rata-rata kedalam kategori aktivitas belajar, kedua kelas tersebut memiliki aktivitas belajar berkategori sama yaitu cukup aktif. Berdasarkan hasil penelitan, aktivitas mengajar guru yang menggunakan pendekatan konvensional dengan media gambar lebih aktif dibandingkan aktivitas guru yang menggunakan pendekatan lingkungan alam sekitar. Hal ini dapat dilihat dari data observasi aktivitas guru rata-rata aktivitas guru pada kelas kontrol sebesar 3,56, sedangkan pada kelas eksperimen sebesar 3,42. Dengan demikian, dapat diketahui bahwa aktivitas mengajar guru yang menggunakan pendekatan kkonvensional dengan media gambar lebih tinggi jika dibandingkan dengan aktivitas guru 
menggunakan pendekatan lingkungan alam sekitar. Akan tetapi, kategori aktivitas guru, sama-sama memilki kategori aktivitas sangat aktif.

Berdasarkan hasil penelitian pada kelas eksperimen diperoleh nilai $t_{\text {hitung }}(7,580)>t$ tabel(df:15) $(2,145)$, dan nilai $p(0,000)<$ dari 0,05 , dengan hasil penelitian tersebut diartikan bahwa ada peningkatan hasil belajar siswa Kelas V SD N 3 Kleteran menggunakan pendekatan lingkungan alam sekitar. Sehingga hipotesisnya menyatakan terdapat hubungan yang signifikan antara pendekatan lingkungan alam sekitar dengan hasil belajar siwa pada materi penyesuaian diri makhluk hidup dengan lingkungan di kelas V SD Negeri 3 Kleteran Grabag Magelang.

Peningkatan hasil belajar siswa kelas V SD N 3 Kleteran pada kelas eksperimen diperoleh sebesar 33,99\%. Sedangkan pada kelas kontrol diperoleh peningkatan persentasenya sebesar 30,95\%. Melihat hasil tersebut mengindikasikan bahwa Pendekatan Lingkungan Alam Sekitar (PLAS) memperoleh hasil belajar yang lebih tinggi dibandingkan dengan pendekatan konvensional dengan media gambar. Sehingga Pendekatan Lingkungan Alam Sekitar (PLAS) merupakan pendekatan yang cukup efektif dalam meningkatkan hasil belajar IPA. Pendekatan Lingkungan Alam Sekitar merupakan suatu pendekatan pembelajaran yang berusaha untuk meningkatkan keterlibatan siswa melalui pendayagunaan lingkungan sebagai sumber belajar. Dalam pembelajarn IPA materi penyesuaian diri makhluk hidup dengan lingkungan siswa dapat mengembangkan rasa ingin tahu, pengetahuan, pemahaman konsep dan kesadaran tentang adanya hubungan yang saling mempengaruhi antara IPA dan lingkungan terutama menggunakan pendekatan lingkungan alam sekitar yang secara langsung dialami oleh siswa. Selain itu siswa dapat menumbuhkan keberanian dan mendorong kemauan dan kemampuan mengumpulkan informasi untuk menyelidiki alam sekitar, memecahkan masalah dan membuat keputusan.

Melalui pendekatan lingkungan alam sekitar, siswa dapat berpengaruh pada hasil belajar siswa untuk mengasah kemampuan pengetahuan, sikap ilmiah dan rasa ingin tahu serta memelihara lingkungan alam sekitar. Selain itu, pembelajaran dengan mengunakan pendekatan lingkungan dapat dimanfaatkan siswa sebagai sumber belajar dan pemberian pengalaman-pengalaman langsung kepada siswa untuk keperluan pengajaran dalam rangka mencapai tujuan pembelajaran.

\section{SIMPULAN}

Berdasarkan pada berbagai kajian teori dengan didukung oleh hasil analisis data serta pembahasan yang telah dilakukan, maka beberapa yang dapat disimpulkan dari pelaksanaan penelitian ini adalah bahwa Ha yang berbunyi "Hubungan Pendekatan Lingkungan Alam Sekitar dengan Hasil Belajar Siswa Materi Penyesuaian Diri Makhluk Hidup" dapat diterima, sehingga Ho ditolak. Dengan hasil perhitungan pada kelompok eksperimen diperoleh nilai $t_{\text {hitung }}(7,580)>\mathrm{t}$ tabel(df:15) $(2,145)$, dan nilai $p(0,000)<$ dari 0,05 , dengan hasil penelitian tersebut diartikan bahwa ada peningkatan hasil belajar siswa Kelas V SD N 3 Kleteran menggunakan Pendekatan Lingkungan Alam Sekitar (PLAS) yang signifikan terhadap hasil belajar siswa. Sehingga dapat disimpulkan terdapat hubungan yang signifikan antara pendekatan lingkungan alam sekitar dengan hasil belajar siwa pada materi penyesuaian diri makhluk hidup dengan lingkungan di kelas V SD N 3 KleteranGrabag Magelang.

\section{DAFTAR PUSTAKA}

Agung, A. A. Gede 2011. Metodologi Penelitian Pendidikan Suatu Pengantar. Singaraja: Undiksha.

Arikunto, Suharsimi. 2013. Dasar-Dasar Evaluasi Pendidikan. Jakarta: PT. Bumi Aksara. 
Desmita. 2012. Psikologi Perkembangan. Bandung: PT. Remaja Rosdakarya. Dimyati \&Mudjiono. 2013. Belajar dan Pembelajaran. Jakarta: Rineka Cipta.

Hamzah B. Uno, Nurdin Mohammad. 2015. Belajar Dengan Pendekatan PAILKEM. Jakarta: PT. Bumi Aksara.

Mulyasa, E. 2011. Kurikulum Tingkat Satuan Pendidikan. Bandung: PT Remaja Rosdakarya.

Sudjana, Nana. 2016. Penilaian Hasil Proses Belajar Mengajar. Bandung: PT Remaja Rosdakarya.

Sugiyono. 2013. Metode Penelitian Tindakan Pendekatan Kuantitatif, Kualitatif dan R\&D. Bandung: Alfabeta.

Sugiyono. 2013. Statistika untuk Penelitian. Bandung: Alfabeta. 